\title{
振動性インパルス電圧に対する $\mathrm{SF}_{6}$ 中 くさびギャップにおける部分放電特性
}

$\begin{array}{llllll}\text { 正員 乾 } & & \text { 昭 } & \text { 文 } & \text { (東 芝) } \\ \text { 正員 寺 } & \text { 西 } & \text { 常 } & \text { 治 } & \text { (東 芝) } \\ \text { 正 員 村 } & \text { 瀬 } & & \text { 洋 } & \text { (東 芝) } \\ \text { 正 員 柳 } & \text { 父 } & & \text { 悟 } & \text { (東 芝) }\end{array}$

\section{Characteristics of Partial Discharge in $\mathrm{SF}_{6}$ Gas Wedge Gap against Oscillating Impulse Voltages}

Akifumi Inui, Member, Tsuneharu Teranishi, Member, Hiroshi Murase, Member, Satoru Yanabu, Member (Toshiba)

It has been reported that there exists a significant difference between the $\mathrm{AC}$ and impulse partial discharge characteristics of a wedge gap in $\mathrm{SF}_{6}$ gas. To clarify this, the partial discharge characteristics against polarity-reversing oscillating impulse voltages with relatively high frequency of 5.4 to $154 \mathrm{kHz}$ have been studied. At low gas pressures, the partial discharge inception voltage(PDIV) is almost independent of the frequency and attenuation factor of the applied oscillating voltage, and shows fairly good agreement with PDIV of lightning impulses. On the contrary, at high gas pressures, the PDIV becomes lower as the attenuation factor decreases than the value of lightning impulses and the calculated breakdown voltage of $\mathrm{SF}_{6}$ gas. It is considered that residual charges remained in the wedge gap are responsible for these phenomena.

キーワード： $\mathrm{SF}_{6}$ ガス, くさびギャップ，振動性インパルス電圧，部分放電

\section{1. まえがき}

$\mathrm{SF}_{6}$ ガスは絶縁性能に優れ, 高電圧機器の絶縁媒体 として広く用いられている。近年, 機器の高電圧化が 進む中，絶縁耐力の向上を図り信頼性を高めるため, $\mathrm{SF}_{6}$ ガス箪体の絶粶特性の研究に加えて, 固体絶緑物 との複合絶縁特性に関する研究が進められている。複 合絶緑に扔いては，いわゆるトリプルジャンクション が形成されることが多く，また固体絶縁物どうしが接 触するような構造は実器の絶縁構成では避けられない 構造である。このような部分の $\mathrm{SF}_{6}$ ガス中複合絶縁 特性についての研究が実験的に行われる一方, 理論的 な解析も進められている(1)〜(3)。

ところが，複合絶緑構成においては，特に実器に対 しては部分放電特性が重要であるにもかかからず, 現
象が複雑であるため未解明な部分が多く, 部分放電機 構に関する研究が十分ではないのが実状である。 このような点をふまえ，著者らは，先に固体絶縁物 としてポリエチレンテレフタレート (PET) フィル ムを用い, 固体絶縁物間にはさまれ連続的にギャップ 長が変化するようなくさび状ガスギャップでの部分放 電特性を光学的手法を導入して調査した ${ }^{(4)}$ 。その結 果，くさびギャップでの部分放電特性においては，交 流とインパルス電圧による部分放電開始電圧に大きな 差が認められ，交流に比べ雷インパルスでは 1.5〜1.8 倍部分放電開始電圧が高くなることが明ら かになった。 また，特に高ガス圧力では，パッシェン の法則から求まるくさびギャップにおける $\mathrm{SF}_{6}$ ガス の計算破壊電圧に比ベ，インパルスでは部分放電開始 電圧が高く，艾流では低くなることも明らかにな 
った。

このようなくさびギャップ特有の部分放電特性は, くさびギャップにおける初期電子の不足やくさびギャ ップに残留する電荷に起因すると考えられ，交流では 電圧極性の反転が部分放電開始電圧に影響していると 推察される。

そこで本論文では, 特にくさびギャップに残留する 電荷と電圧極性の反転が部分放電開始に及ほすす影響を さらに明確にするため, 零点を切る減衰振動性のイン パルス電圧により部分放電開始電圧を調査した結果を 報告する。すなわち， $5.4 \sim 154 \mathrm{kHz}$ の比較的高周波 の振動成分をもつ零点を切る減衰振動性インパルス電 圧により，くさびギャップでの部分放電開始電圧を振 動の周波数と波形の減衰を変えて求めた。そして, 電 荷の移動と抎散の関係から残留電荷と印加電圧の極性 反転の影響について検討した。

\section{2. 試験方法}

〈2・1〉 電極構成電極構成を図 1 に示す。上部 リング電極を高圧電極とし，PET フィルム（厚さ 25 $\mu \mathrm{m}$, 比誘電率 3.2 ) により厚さ $1.0 \mathrm{~mm}$ の被履を施 した。下部平板電極を接地電極とし，リング電極と平 板電極の間に PET フィルム（厚さ $100 \mu \mathrm{m}$, 幅 200 $\mathrm{mm} \times 200 \mathrm{~mm}$ ) を厚さ $1.1 \mathrm{~mm}$ となるよう積層して 挟み、フィルム間にくさびギャップを形成した。

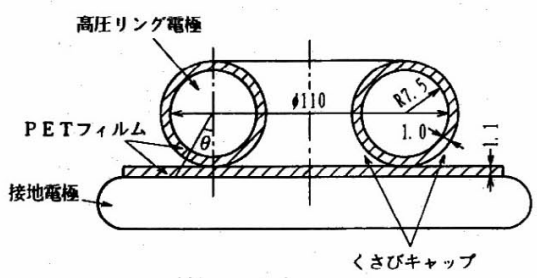

図 1 電極構成

Fig. 1. Electrode configuration.

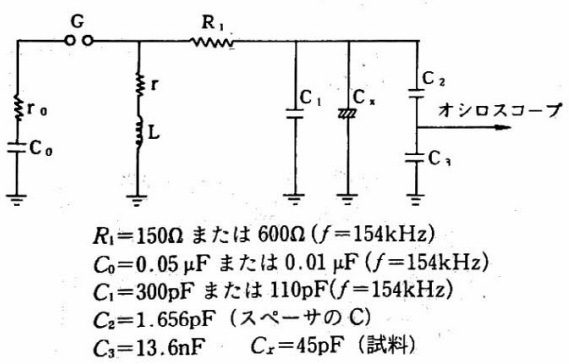

図 2 振動波発生回路

Fig. 2. Generating circuit of oscillating impulse voltages.
試験は所定の $\mathrm{SF}_{6}$ ガス圧力 $(P=0.2,0.35$, $0.45 \mathrm{MPa}$ ) を封入した試験用圧力タンクにて外部から の光の入射を一切遮断して暗中にて行い, 部分放電に 伴う微小発光を観測した。

\section{〈2・2〉振動性インパルス電圧発生回路}

零点を切る減衰振動性インパルス電圧は, 図 2 に示 すようにコンデンサ $C_{0}$ に充電された電荷を試料の電 極と並列に接続したインダクタンス $L$ を通して放電 させる回路で発生させた。発生電圧の振動周波数 $f$ はコンデンサ $C_{0}$ とインダクタンス $L$ の值を変えて変 化させ, 減衰率は $L$ に直列に入る抵抗 $r$ または $C_{0}$ に直列の抵抗 $r_{0}$ を変えて変化させた。また，第 1 波

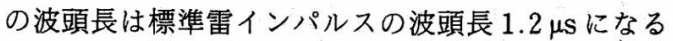
ようにした。ただし，振動周波数が高くなると第 1 波 の波高值を低下させることなく波頭長を $1.2 \mu \mathrm{s}$ に合 せることは困難であるため $154 \mathrm{kHz} て ゙ は$ 波頭長を $0.2 \mu \mathrm{s}$ とした。

なお, 電圧波形は試験用タンクのスペーサがもつ漂 遊キャパシタンス $C_{2}$ を用いた容量分圧器により測定 した ${ }^{(5)}$ 。これは試料と並列に抵抗分圧器を設けて測定 する抵抗分圧法では分圧器の抵抗が回路の減衰に大き く影響を及ぽし，減衰の小さい波形が得にくくなるた めである。

試験した振動性インパルス電圧の波形定数を表 1 に, 電圧波形の一例を図 3 に示す。ここでは振動の減

表 1 回路定数と波形定数

Table 1. Circuit parameters and waveform parameters.

\begin{tabular}{c|c|c|c|c}
\hline$L(\mathrm{mH})$ & $r(\Omega)$ & $r_{0}(\Omega)$ & $f(\mathrm{kHz})$ & $\begin{array}{c}\text { 半隇周波数 } \\
\text { (サイククル }\end{array}$ \\
\hline 17.2 & 1.95 & 0 & 5.4 & 4.86 \\
\hline$\prime \prime$ & 1.95 & 150 & $n$ & 0.919 \\
\hline 2.6 & 0.650 & 0 & 11.1 & 5.89 \\
\hline$" 1$ & 0.650 & 30 & $n$ & 1.78 \\
\hline 0.0867 & 0.502 & 0 & 72.5 & 3.33 \\
\hline 0.111 & 0.195 & 0 & 154 & 3.71 \\
\hline$\prime \prime$ & 10.3 & 0 & 154 & 1.33 \\
\hline
\end{tabular}

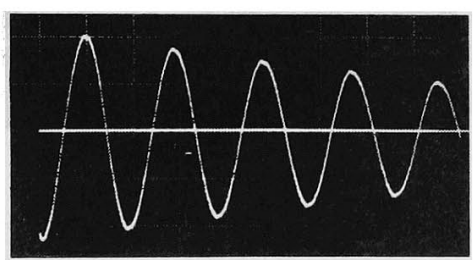

図 3 印加電圧波形

Fig. 3. Oscillogram of applied voltage wave form. 
衰を表す定数として半減周波数を用いた。これは，振 動波の包絡線が半波高值になる時間を振動周期で除し たものである。なお, 振動周波数と半減周波数はオシ ログラムから求めた。

〈2・3〉 電圧印加方法と部分放電測定 各振動性 インパルス電圧を $10 \mathrm{kV}$ から $5 \mathrm{kV}$ ステップにて上昇 させ, 各ステップ 1 回ずつ印加する。第 1 波の電圧極 性が正極性の場合と負極性の場合のそれぞれについ て，部分放電開始電圧を求めた。

部分放電の観測は, 先の雷及び開閉インパルス電圧 による部分放電検出の場合と同様の方法を用いた ${ }^{(4)}$ 。

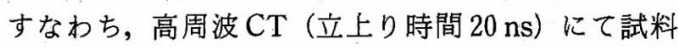
の接地電流波形を測定し, 電流波形の変化から検出す ると共にイメージインテンシファイヤ (I. I. 光增倍率 44,000 倍）により部分放電に伴う発光を撮影した。ま た，今回，集光レンズを取付けてくさび部分に焦点を 合せ, 光ファイバを通してフォトマル (PM 分光感度 波長範囲 400 1,200 nm）により微小発光の観測も行 い, 印加電圧波形と部分放電発生の経時的な関係も調 査した。

\section{3. 試験結果}

零点を切る振動性インパルス電圧を印加すると, 部 分放電開始電圧にて電流波形が変乘し, くさびギャッ プでストリーマによる微小な発光が生じるのが, PM およびI.I.にて観測される。

部分放電開始時の部分放電による微小発光を PM

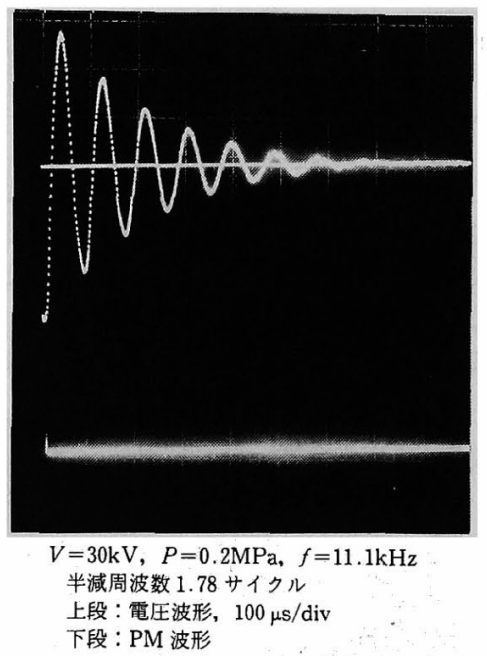

図 4 部分放電による発光に対するPM波形

Fig. 4. Oscillogram of PM to the partial discharge.
により検出した例を図4，図5に，I.I.によりとらえた 一例を図 6 に示す。図 4 は, ガス圧力 $P$ が $0.2 \mathrm{MPa}$ で $f=11.1 \mathrm{kHz}$, 半減周波数が1.78サイクルの場合 の電圧波形とそれに対応するPM の出力波形である。 電圧波形の第 1 のピークに対応してくさびギャップで 発光するのが PMの波形よりわかる。これに対し, 図 5 は $P$ が $0.45 \mathrm{MPa} て ゙ f=11.1 \mathrm{kHz}$, 半減周波数 が 5.89 サイクルの場合の例である。電圧波形の第 1 のピークでは発光せず, 逆極性となる第 2 のピークお よび電圧が低くなる第 4 , 第 5 のピークでも発光する のがわかる。なお，この部分放電が発生する時間遅れ に対しては，第 1 波の電圧極性による差は認められな かった。図 6 はこのときのI.I.によりとらえたくさび ギャップでの発光静止写真である。これは図 1 に示す 電極構成においてくさびギャップを水平方向真横から 撮影したもので, くさびギャップ部分で一様に発光が 生じている。なお電流波形が変わいする電圧と, 微小 発光が観測される電圧は一致した。また, 電流波形に 変わいが生じる時間と PMにより発光が観測される 時間は一致した。このような電気的手法と光学的手法 の両者で部分放電が確認される最小の電圧を部分放電 開始電圧とした。くさびギャップでの部分放電は, 最 小検出感度 $0.3 \mathrm{pC}$ で測定した交流部分放電特性によ

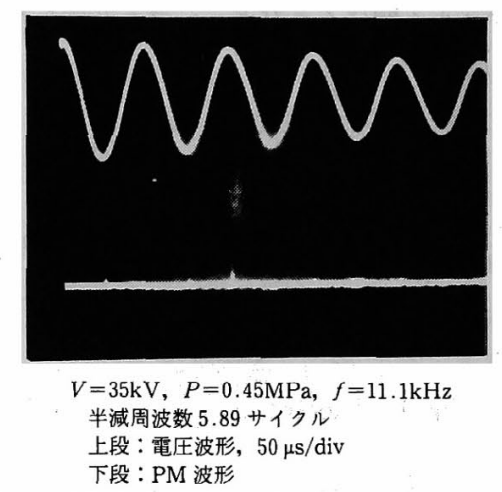

図 5 部分放電による発光に対するPM波形 Fig. 5. Oscillogram of PM to the partial discharge.

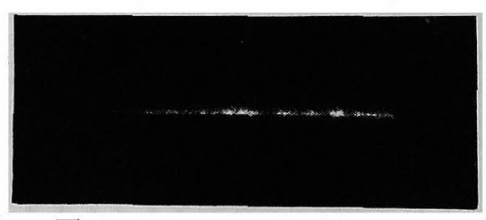

図 6 I.I.による放電静止写真 Fig. 6. Partial discharge photograph with I. I. 


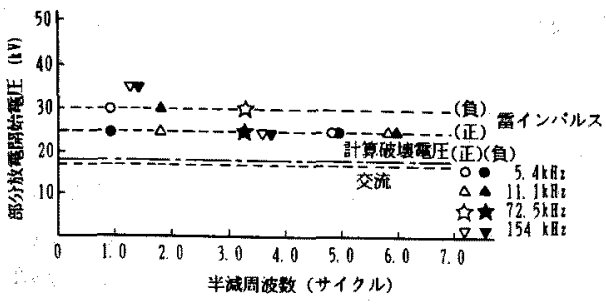

図 7 半減周波数と部份放電開始電圧 $(P=0.2 \mathrm{MPa})$

Fig. 7. Relation between partial discharge voltage and half reduction frequency $(P=$ $0.2 \mathrm{MPa}$ ).

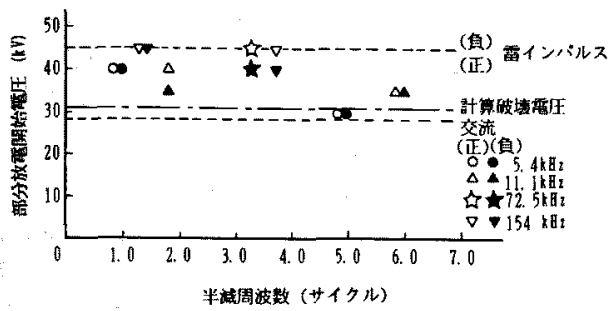

図 8 半減周波数と部分放電開始電压 $(P=0.35 \mathrm{MPa})$

Fig. 8. Relation between partial discharge voltage and half reduction frequency $(P=$ $0.35 \mathrm{MPa}$ ).

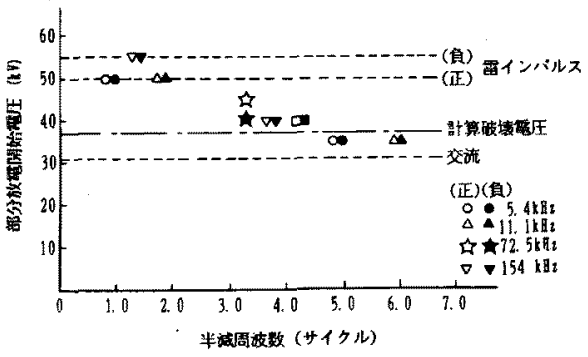

図 9 半減周波数と部分放電開始電圧 $(P=0.45 \mathrm{MPa})$

Fig. 9. Relation between partial discharge voltage and half reduction frequency $(P=$ $0.45 \mathrm{MPa}$ ).

ると, 部分放電開始電圧以上の電圧に対し放電電荷の 上昇が急激であり，しかも部分放電開始電圧で数十 $\mathrm{pC}$ の部分放電が急に出始めるのが特幑である(4)。イ ンパルス部分放電開始にても微小光による検出と電流 波形による検出が一致して扣り，また，交流部分放電 特性と同様に部分放電の発生が電圧変化に対し急激で あることから，部分放電開始電圧としては精度良く湘 定できていると考えられる。

電学論A, 110 巻 12 号, 平成 2 年
図 7〜図 $9 に$ 各ガス压力に扔ける部分放電開始電㞋 を半減周波数を横軸にとって示した。罒中には，同条 件により試験した雷インパルス電圧と交流電圧（波高 値）での部分放電開始電圧を破線で，またくさびギャ ップに拈いて $\mathrm{SF}_{6}$ ガスのパッシェン曲線から求めた $\mathrm{SF}_{6}$ ガスの計算破壊電圧を一点鎖線で示す(4)。

$P$ が $0.2 \mathrm{MPa}$ と低いときは， $f$ が $154 \mathrm{kHz}$, 半隇 周波数が 1.33 サイクルの場合を除いて周波数や半減 周波数にかかわらず，ほほ雷インパルス部分放電開始 電圧と同レベルである。

これに対し $P$ が $0.35 \mathrm{MPa}$ と高くなると, 半隇周 波数が小さいときは雷インパルス部分放電開始電圧と 活ほ等しいが，半減周波数が大きく減衰の小さい振動 性インパルス電圧では印加電生極性反転の影響が現 れ，部分放電開始電圧が低下する。この傾向は $P$ が

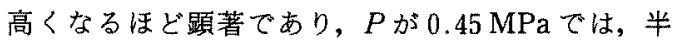
減周波数の増加にともない部分放電開始電压が低下す る割合は大きくなる。なお，部分放電開始電圧には第 1 波の電圧極性の違いによる顕著な差は認められな い。これ㹥くさびギャップが非常に短ギャップでかつ ほぼ対称なギャップであるためと考えられる。

\section{4. 検討}

〈4・1〉電圧極性反転の影響図7〜図9に示し たように零点を切る振動性インパルス電压の部分放電 開始電圧と振動周波数および半減周波数との関係は, ガス圧力 $P$ が低い場合と高い場合でその傾向が異な る。すなわち，Pが $0.2 \mathrm{MPa}$ と低いときは半隇周波 数にかかわらず部分放電開始電圧はほぼ雷インパルス の場合と等しいのに対し，Pが高くなると半減周波 数の増加に伴い部分放電開始電圧の低下が認められる ようになる。

更に，Pにより図4，四 5 に示すよろに部分放電が 発生する時間遅れも買なる。すなわち，Pが低い 0.2 $\mathrm{MPa}$ では印加電圧の第 1 のピークに活济対応して部 分放電が発生する。これに対し， $P$ が $0.45 \mathrm{MPa}$ と 高がス圧力になると第 1 のピークでは部分放電が発生 せず，逆極性となる第 2 のピークで始めて部分放電が 発生し，また電圧が低くなる第 4, 第 5 のピークでも 部分放電が発生する。このことは極性反転の影響によ り，低い電圧でも部分放電が生じることを示して いる。

ここで, 部分放電開始電压にて，第 1 のピークで部 分放電が生じる割合と $\mathrm{SF}_{6}$ ガス圧力の関係を示した 結果の一例を図 10 に示す。これは $f$ が $5.4 \mathrm{kHz}$ と $11.1 \mathrm{kHz}$ および $154 \mathrm{kHz}$ における, それぞれ半減周 


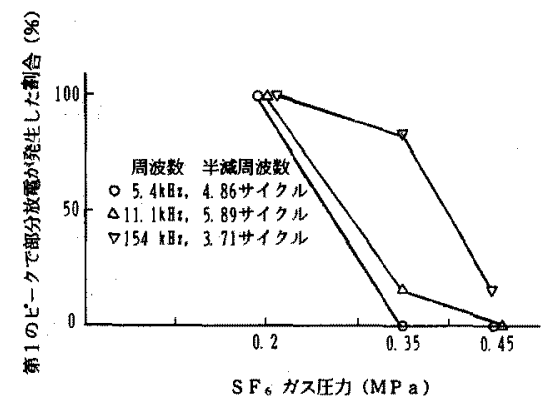

図 10 第 1 のピークで部分放電が発生した 割合と $\mathrm{SF}_{6}$ ガス压力の関係

Fig. 10. Relation between discharge inception probability in the first peak and $\mathrm{SF}_{6}$ gas pressure.

波数の大きい場合について，第 1 波の電压極性が正の 場合，負の場合すべてを含めて図示したものである。 $P$ が低いときは第 1 のピークで部分放電が $100 \%$ 発生 し，極性反転の影響が生じないのに対し，Pが高く なると第 2 のピーク以降で部分放電が発生する確率が 高くなり，高がス压力では極性反転の影響が大きく現 れている。

ところで，標準雷インパルス電死に対するくきびギ ヤップの部分放電開始電纴はパッシェン曲線から求ま る $\mathrm{SF}_{6}$ ガスの計算破壊電圧よりも高くなりこれは 初期電子不足に起因していることを前報で示した(4)。 すなわち, $P$ が $0.2 \mathrm{MPa} と$ 低いときは, 紫外線を照 射して初期電子を十分供給してやると雷インパルス部 分放電開始電圧は $\mathrm{SF}_{6}$ ガスの計算破壊電生にほぼ一 致するが，外部からの光の入射を一切遮断すると，イ ンパルス電压の極性によっても異なるが, $\mathrm{SF}_{6}$ がスの 計算破壞電圧の1.5 倍前後に上昇する。これが図 70 一点鎖線（計算值）と破線（雷インパルスに対する部 分放電開始電圧）の差である。なお，光の入射がない 状態において，低ガス压力，短ギャップでは初期電子 の発生はガス中のイオンの電子放出であると考えら れ，ガスギャップのイオン密度が $10 \sim 100$ 個 $/ \mathrm{cm}^{3}$ 程 度であると仮定するとうまく説明ができることが報告 されている ${ }^{(6)}$ 。更に前報では，高ガス圧力になるほ ど，紫外線昭射による初期電子供給の影響が現れにく くなり, 部分放電開始電圧が計算值より高くなる原因 としてくさびギャップに残留する電荷の影響も考える ベきであることを示した(4)。

今回，振動波による実験によって，以下に述べるよ うに，残留電荷の影響が更に明らかになったと考え 万。
すなわち，Pが $0.2 \mathrm{MPa}$ の低ガス圧力において， 振動性インパルス部分放電開始電圧が半減周波数にか かわらすほほ雷インパルスの場合と等しく，電圧極性 が反転する影響が生じていないのは，本実験の周波数 範囲では初期電子の不足に起因するものが支配的であ るためと考えられる。なお， $f$ が $154 \mathrm{kHz}$ ，半減周波 数が 1.33 サイクルの場合, 部分放電開始電圧が雷イ ンパルスの場合より高い。これは，周波数が高く減衰 が大きいため印加時間が短く, 初期電子の不足と放電 の時間遅れの関係から， $V-t$ 特性によって部分放電 開始電圧が上昇したからであると考えられる。

これに対し，Pが $0.35 \mathrm{MPa}$ 以上になると，初期 電子不足により部分放電開始電圧が高くなる効果以上 に電圧極性が反転する影響が現れ，半減周波数が大き くなると部分放電開始電压が低下する傾向が見られ る。特に, $P$ が $0.45 \mathrm{MPa}$ と高ガス圧力になると, 半滅周波数が大きい場合, 部分放電開始電圧の低下が 顕著になり，パッシェン曲線から求まる $\mathrm{SF}_{6}$ ガスの計 算破壊電圧よりも低下する。

このように高がス圧力ほど電圧極性反転の影響が大 きいのは，次のようにくさびギャップの残留電荷を考 えると説明できる。

くさびギャップの電界は, 接触部に近づくにつれて 急激に高くなる。従って，くさびギャップのギャップ の長さの短い部分では部分放電開始電圧以下の電圧で $\mathrm{SF}_{6}$ ガスの電離電界を越えており電子なだれが発生し ていると考充られる。電気力線に沿ったギャップの長 さを電離距離とすると、この電離距離が短いためスト リーマに転移せず，くさび部のガスの破壊には至らな い。なお，くさびギャップの部分放電はくさび部のガ スの破壊によって発生するものと予想される(4)。くさ びギャップ中には $\mathrm{SF}_{6}$ の電離係数 $\alpha$ 相当分の正イオ ン, 付着係数 $\eta$ 相当分の負イオン, $(\alpha-\eta)$ 相当分の 電子が生じ,これらが正, 負電荷としてくさびギャプ 間に残留していると考えられる。振動性インパルス電 圧の印加により第 1 の半波で生じた電荷がくさびギャ ップに残留している時に, 続いて極性の反転された電 圧が印加されるため, 局部的に高電界部行が形成され 部分放電の発生が容易となる。

また，ガス圧力が高いほど臨界電界が高く，印加電

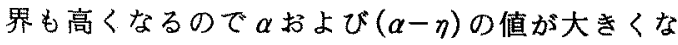
り, 作られる電荷の数もガス圧力に対し指数関数的に 多くなる。促って，高ガス圧力ではくさびギャッブに 残留する電荷の影響が顕著になるものと思われる。

このように，振動性インパルス電圧では，くさびギ ヤップに電荷が残留しているときに極性の反転する電 
圧が続いて印加されることが部分放電開始電压を低下 させていると推定される。そこで, 残留電荷の影響を 電荷の移動と拡散の関係から考察する。

〈4・2〉 残留電荷の影響 くさびギャップ中に残 留する電荷を $\mathrm{SF}_{6}$ ガスの電離および付着から生じる イオンの移動と搪散から検討する。なお，電子なだれ によって発生した電子は $\mathrm{SF}_{6}$ ガスに捕えられ貝イオ ンを作るので，負電荷としては電子より負イオンが有 効であると考えられる。

振動性インパルス電圧の第1の半波で生じた電子な だれによるイオンがくさびギャップを渡り切り，くさ びギャップに残留していると，逆極性電圧となる次の 半波により局部的に高電界部分が形成されると考えら れる。このためには，正・負イオンが半波の間にギヤ ップを渡り切らなければならない。

$\mathrm{SF}_{6}^{+}$イオンならびに $\mathrm{SF}_{6}^{-}$イオンの移動度 $\mu$ は $\alpha$

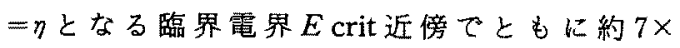
$10^{-5} \mathrm{~m}^{2} / \mathrm{V} \cdot \mathrm{s}$ であり(7),これより電界の低いときは電

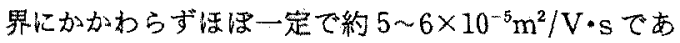
ることが報告されている(7)。ここで，パッシェン曲線 を満たす $\mathrm{SF}_{6}$ ガスの最小破壊電压となるのは，本電 極形状では図 1 に示すくさび部の角度 $\theta$ が約 $10^{\circ} の$ 部分であり(4)，電気力線に沿ったギャップの長さ $d$ 岅約 $0.13 \mathrm{~mm}$ となる。また, この位置より $\theta$ の小さ いギャップの長さの短い部分では $\mathrm{SF}_{6}$ ガスの笔離電 界を越えて㧍り正・負イオンが発生する。このギャッ

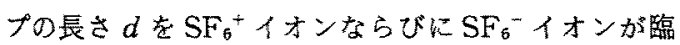
界電界 $E$ crit の上きに渡るのに要する時間 $t$ は，おお む权次式で与えられる。

$$
t=\frac{\sqrt{2} d}{\mu E \text { crit }}
$$

なお, 上式では印加電圧を正弦波とし, 移動度 $\mu$ は 一定であると仮定している。(1)式より $\theta$ が約 $10^{\circ}$ のくさびギャップを渡る時間を計算すると，ガス圧力 が高いほど臨界電界结高いのでギャップの長さを渡り 切る時間は短くなるが，本試験のがス圧力範囲である $0.2 \sim 0.45 \mathrm{MPa}$ では約 $0.15 \sim 0.07 \mu \mathrm{s}$ となる。この時 間は $154 \mathrm{kHz}$ までの周波数範围では, 印加電圧の半 波の間に十分ギャップを渡り切ることのできる時間で ある。次に搪散を考光ると，例えば $\mathrm{SF}_{6}$ イインの搪 散係数 $D_{i}$ は $D_{i} / \mu$ として臨界ストレスよりやや低い 領域で $0.149 \mathrm{~V}$ と与えられている ${ }^{(7)(8)}$ 。この值を用い

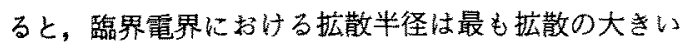
$0.2 \mathrm{MPa}$ の低ガス压力においても，ギャップの長さ に比へ約 2 けた低い值であり，イオンの移動に比く拡 散は非常に小さい。
以上のイオンの移動と㹡散の関係加次のように考 えることができる。高ガス圧力では臨界電界が高くな るので発生する電子・イオンの数は多くなり、これら のイオンは振動性インパルス電圧の半波の間にギャッ ブを渡り切り，正・負電荷としてくさびギャップに残 留する。半減周波数の大きい波形では逆極性となる後 続の波形により局部的な高電界部分が形成され部分放 電の発生が容易になる。半隇周波数が大きくなるとパ ッシェン曲線から求まる $\mathrm{SF}_{6}$ ガスの計算破䁲電圧よ り低下するのはこのためであろう。更に，図 5, 図 10 に示すように電压の第 1 のピークで部分放電が発生せ ず，第2のピーク以降で部分放電が発生すること牥こ のことを赛付けている。なお，半減周波数の小さい波 形では後続の電圧が低くなるため，残留電荷の影響が 生じず部分放電開始電圧の低下は生じなかったものと 考えられる。

以上のように，くさびギャッフでは電子なだれによ る電荷が残留し，特にガス圧力が高くなるとこの残留 電荷が部分放電開始電界に大きく影響を与えると考え られる。前報 ${ }^{(4)} に$ にいて, 交流部分放電開始電圧が計 算值より低下しインパルス比が高くなったのも，この 残留電荷の影響と考えられる。

\section{5.まとめ}

$\mathrm{SF}_{6}$ ガス中, 絶縁物 (PETフィルム) 間に形成さ れるくさびギャップにおける部分放電開始電圧を, 零 点を切る隇衰振動性インパルス電圧により調查した。 振動の周波数と波形の減衰を变えて部分放電開始電圧 を求めたところ次の事項が明らかとなった。

(1) $\mathrm{SF}_{6}$ のガス圧力が $0.2 \mathrm{MPa}$ の低ガス圧力に おいては，振動性インパルス電圧の部分放電開始電圧 は周波数色半隇周波数にかかわらず，ほほ雷インパル ス部分放電開始電圧と等しくなる。これは低ガス圧力 ては初期電子の不足か゚インパルス部分放電開始電圧を 高める効果が大きいためであり，電圧極性が反転する 影響は生じない。

（2）ガス圧力が高くなると半隇周波数の大きな振 動性インパルス電死では部分放電開始電仕が低下す る。これはくさびギャップに残留する電荷と印加電圧 の極性が反䎐する影響によるものと考えられる。

このように, $\mathrm{SF}_{6}$ ガス中絶緑物で被履されたくさび ギャップにおける部分放電開始特性には，印加電圧の 極性反転が大きく影響することがわがり， $\mathrm{SF}_{6}$ ガス中 複合絶緑における部分放電現象の一端が明らかにな つた。

(平成 2 年 3 月 6 日受付, 同 2 年 10 月 11 日再受付) 


\section{文 献}

（1）宅間・河本：「絶緑物が電極と接したとき」, 電気学会放電研 資, ED-83-14（昭 58)

（2）宅間·河本：「絶緑物が霓極と接したとき(続)」,同上,ED-83 -50 (昭 58)

（3）放電常置専門委員会「SF 6 ガス中の支持絶縁物における沿面 放電特性」, 電気学会技報 (II 部)，83(昭 54)

（4）乾・寺西・大久保・柳父：「SF五ガス中くさびギャップにおけ 万部分放電特性」, 電学論 A, 110, 101 (平成 2-2)

(5) H. Murase. I. Ohsima, et al. : "Measurement of Transient Voltages Induced by Disconnect Switch Operation.", IEEE Trans. Pou'er Apparatus Syst., PAS. 104, 157 (1985)

（6）花井・寺西・大久保・柳父：「SF ンパルス電压に対する絶緑特性」, 電学論 A 109,255 (平成 元-6)

(7) R. Morrow : "A Survey of the Electron and Ion Transport Properties of $\mathrm{SF}_{6}{ }^{\prime \prime}$, IEEE Trans. Plasma Sci., PS-14, 234 (1986)

(8) M. S. Naidu \& A. N. Prasad: J. Phys. D., 3, 951 (1970)

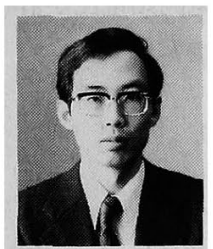

事。IEEE 会員。

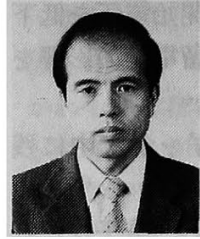

寺 西 常 治 (正員)

昭和 21 年 2 月 10 日生。 48 年 3 月名古屋大学大学院博士課程修了。 同年 4 月 (株) 東芝入社。変圧器開発 設計に従事。 54 年より, 主として, 変圧器絶緑技術に関する研究に従事。工学博士。

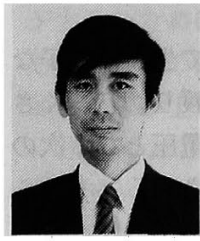

\section{村 瀬 洋 (正員)}

昭和 27 年 7 月 9 日生。 55 年 3 月 東京工業大学電気工学専攻博士課程 修了。同年 4 月(株) 東芝入社。高電 圧絶縁現象, GIS 中の急しゅん波サ ージ現象の研究に従事。工学博士。IEEE 会員。

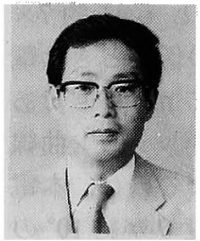

\section{柳父悟（正員）}

昭和 16 年 7 月 15 日生。 39 年 3 月東京大学工学部電気工学科卒業。

\section{乾昭 文（正員）}

昭和 29 年 2 月 5 日生。 54 年 3 月 早稲田大学大学院電気工学専攻修士 課程修了。同年 4 月 (株) 東芝入社。 高電圧絶縁技術に関する研究に従 月 (株) 東芝入社。以来, 高電圧現象, 遮断現象, 高電 圧大電流試験法などの研究, 高電圧開閉保護装置の開 発などに従事。 47 年 Ph. D (Liverpool)，56，63 年 電気学会進歩賞, 58 年同論文賞受賞。IEEE fellow, Current Zero Club 会員。 